\title{
A Study by Fluorescence Microscopy of the Replication of Lymphogranuloma venereum Virus in HeLa Cell Monolayers
}

\author{
By G. FURNESS* AND G. W. CSONKA \\ The Lister Institute of Preventive Medicine, Chelsea, London and \\ St Mary's Hospital, Paddington, London
}

(Received 22 August 1962)

\begin{abstract}
SUMMARY
In HeLa cells infected with a single infectious unit of lymphogranuloma venereum virus and stained with acridine orange, one particle (initial body) of ribonucleic acid (RNA) about $2 \mu$ diam. was seen by fluorescence microscopy in the cell cytoplasm after incubation for $6-8 \mathrm{hr}$. at $37^{\circ}$. After 11-12 hr. of incubation, an average of 2 particles/infected cell was found. Thereafter the number increased exponentially with a mean generation time of 2-21 $\mathrm{hr}$. The particles then remained discrete and in a circumscribed area in the cytoplasm until 18-21 hr., when a vacuole was formed around the initial bodies. By 21-24 hr. smaller particles ranging in diameter from $1 \mu$ to about $0.25 \mu$, and in colour from the orange fluorescence characteristic of RNA to yellowish green, were detected amongst the initial bodies. At $33 \mathrm{hr}$., the initial bodies were almost entirely replaced by smaller particles or elementary bodies, most of which stained yellowish green and had the green fluorescence of deoxyribonucleic acid (DNA) only after treatment with ribonuclease. The elementary body of lymphogranuloma venereum thus consists of a DNA particle surrounded by a layer containing a detectable amount of RNA. After $33 \mathrm{hr}$. the number of elementary bodies decreased; presumably because infective virus had been released, since at $40-44 \mathrm{hr}$. initial bodies appeared in previously uninfected cells. HeLa cells infected with more than one infectious unit often contained more than one focus of infection, indicating that replication is not confined to a single site in the cytoplasm.
\end{abstract}

\section{INTRODUCTION}

During the replication of inclusion blennorrhoea virus in HeLa cells, the formation of ribonucleic acid (RNA) and deoxyribonucleic acid (DNA) particles can be observed by fluorescence microscopy (Furness, Henderson, Csonka \& Fraser, 1962). In the present investigation multiplication of lymphogranuloma venereum virus in HeLa cell monolayers was studied by the same technique and was found to differ in some respects from that of inclusion blennorrhoea virus.

\section{METHODS}

Virus. The JH strain of lymphogranuloma venereum virus (LGV) was grown in HeLa cell monolayers in $250 \mathrm{ml}$. Pyrex feeding bottles. Suspensions were prepared by dispersing monolayers in $10 \mathrm{ml}$. tissue culture medium $47-52 \mathrm{hr}$. after infection

* Present address: Twyford Laboratories Ltd. (Virology Section), 12 Gorst Road, London, N.W. 10. 
and releasing the virus by exposure to ultrasonic vibrations (Furness \& Fraser, 1962). Tissue culture medium consisted of Hanks's balanced saline solution with the addition of $0.25 \%(\mathrm{w} / \mathrm{v})$ lactalbumin hydrolysate, $15 \%(\mathrm{v} / \mathrm{v})$ human serum, $5 \%(\mathrm{v} / \mathrm{v})$ calf serum, $4 \%(\mathrm{v} / \mathrm{v})$ of $1.4 \%(\mathrm{w} / \mathrm{v}) \mathrm{NaH}_{2} \mathrm{CO}_{3}$ and $100 \mu \mathrm{g}$. streptomycin/ $\mathrm{ml}$.

Infection of HeLa cell monolayers for staining purposes. Monolayers on coverslips in Leighton tubes (Furness, Graham \& Reeve, 1960) were covered with 0.25 ml. tissue culture medium and inoculated with $0 \cdot 1 \mathrm{ml}$. of dilutions of virus suspension; after adsorption for $2 \mathrm{hr}$. at $30^{\circ}$ they were freed from unadsorbed virus by washing with phosphate-buffered saline (Dulbecco \& Vogt, 1954), covered with 2 ml. tissue culture medium and incubated at $37^{\circ}$. Sample monolayers were removed at $2-3 \mathrm{hr}$. intervals for staining. To ascertain the number of infectious units adsorbed, monolayers were stained with Giemsa after $48 \mathrm{hr}$. incubation and the inclusions counted at a magnification of $\times 360$ (Furness et al. 1960). Since the monolayers contained about $1.3 \times 10^{6}$ cells, the adsorbed virus/cell ratio could be calculated. It was assumed that single infections had been induced in those monolayers with less than $5 \%$ infected cells.

Specificity of acridine orange staining. Acridine orange stained RNA orange and DNA green by our technique (Furness et al. 1962). Incubation of uninfected and infected monolayers for $1 \mathrm{hr}$. at $37^{\circ}$ in $0.01 \%(\mathrm{w} / \mathrm{v})$ ribonuclease (RNAase) grade A, in McIlvaine's buffer ( $\mathrm{pH} 6.8$ ) and in $0.01 \%(\mathrm{w} / \mathrm{v}$ ) deoxyribonuclease (DNAase) grade B (California Corporation for Biochemical Research, Los Angeles) in veronal

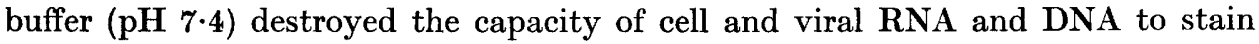
characteristically with acridine orange, thus confirming the specificity of the staining reactions (Furness et al. 1962).

\section{RESULTS}

Cells infected with a single infectious unit. The following growth cycle was observed in HeLa cells growing under optimum conditions and infected with a single infectious unit of LGV. After 6-8 hr. incubation at $37^{\circ}$, a relatively large RNA particle, $2 \mu$ diam. (initial body) was seen in the cell cytoplasm, usually situated away from the nucleus. By 11-12 hr., an average of 2 particles/cell was counted; their number then increased exponentially for at least $18 \mathrm{hr}$. (Pl. 1, fig. 1, 2) with a mean generation time of 2-21 hr. (Fig. 1). Thereafter they continued to multiply but were too numerous to count, although remaining discrete (Pl. 1, fig. 3). The particles remained in a circumscribed area, and at 18-21 hr. were seen within a vacuole which later developed into the characteristic inclusion body. There was no evidence of an enclosing membrane or matrix. Until this time the particles were relatively uniform in size and it was not until 21-24 $\mathrm{hr}$. that smaller RNA particles were detected in the inclusions. Thereafter the initial bodies gradually decreased in number and were replaced by smaller particles varying in size from $1 \mu$ to about $0.25 \mu$ and in colour from the typical orange of RNA to yellowish green (Pl. 1, fig. 4). By 33-36 hr. the contents of the inclusions consisted almost entirely of small yellowish green particles with a few irregular RNA masses larger than the initial bodies. At this time the inclusions contained noticeably fewer particles, suggesting release of virus, and this was confirmed by the detection at $40-44 \mathrm{hr}$. of initial bodies in previously uninfected cells (Pl. 1, fig. 5). We estimated that these 


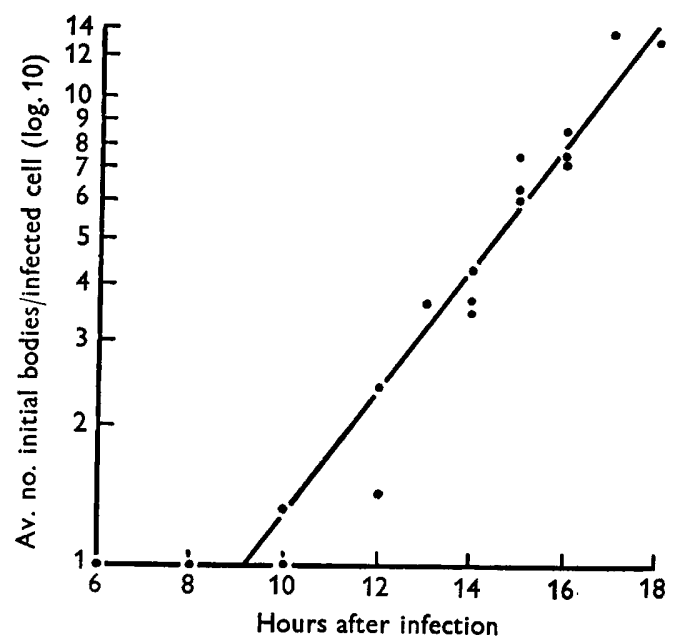

Fig. 1. Multiplication of initial bodies of LGV in HeLa cells infected with a single infectious unit. The points represent the results of four separate experiments.

Table 1. Distribution of initial bodies in HeLa cells infected with several infectious units* of lymphogranuloma venereum virus

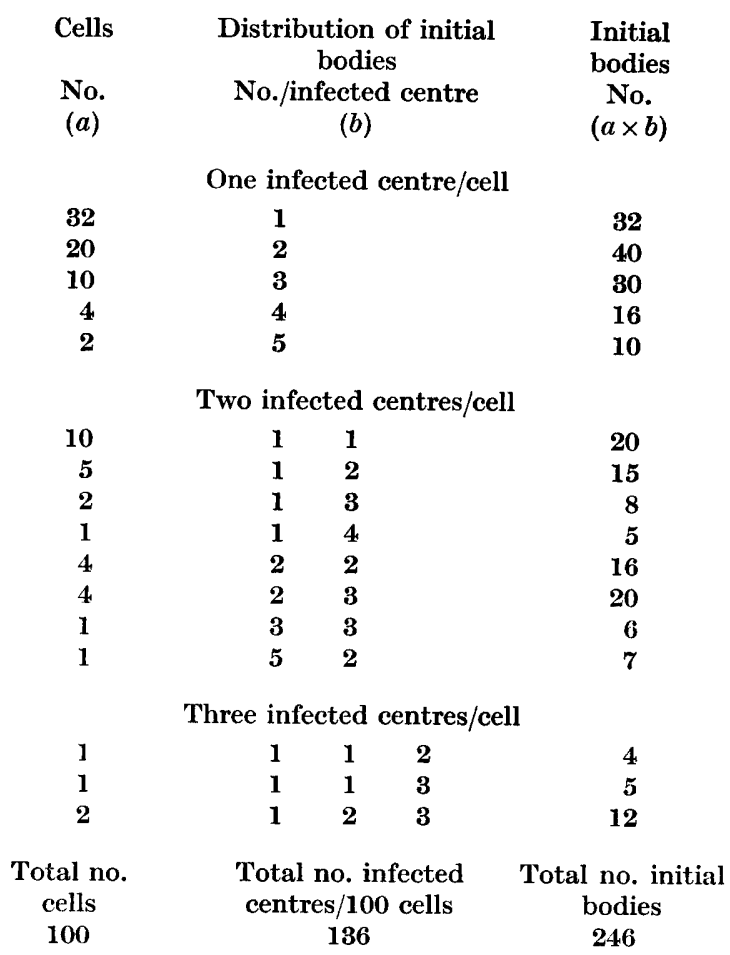

* From titration of original suspension, estimated number of infectious units adsorbed 2.5/cell. 
cells had been infected for 12-14 hr., a period compatible with release of virus from the inclusion about 30-34 hr. after adsorption. Since at this time the yellowish green particles are predominant, it is reasonable to infer that they are the infectious units.

Cells infected with several infectious units. At $9 \mathrm{hr}$. after infection, cells estimated to have adsorbed an average of $\mathbf{2 . 5}$ infectious units contained about this number of initial bodies (Table 1). Of those estimated to have adsorbed 1/10 this number, $95 \%$ of infected cells contained one RNA particle and $5 \%$ two RNA particles. This confirmed that the RNA particles had not yet multiplied (Fig. 1) and suggested that each infectious unit was the precursor of a single initial body. In cells infected with an average of $\mathbf{2 . 5}$ infectious units, the number of sites of infection/cell and of initial bodies/site varied. Of 100 infected cells examined, $68 \%$ contained one infected site and $32 \%$ two or more infected sites. Although the virus readily initiated several foci of infection, which usually coalesced to form a single inclusion, many infected centres contained several initial bodies at the outset, which suggests that there is a preferential site for replication.

The effect of RNAase and DNAase. Although treatment of the infected cells with DNAase abolished the specific colour reaction of the DNA in the cell nuclei, it did not affect the staining reaction of either the initial bodies or the elementary bodies. Treatment with RNAase abolished the orange and yellow staining properties of the initial bodies and elementary bodies respectively, revealing a core of material that stained green like DNA, and that could be digested by DNAase. The orange fluorescence of the initial bodies and the orange/yellow fluorescence of the elementary bodies can be attributed to varying amounts of RNA in the layer surrounding the DNA core.

\section{DISCUSSION}

The growth cycles of the trachoma/inclusion blennorrhoea virus (IBV) and the psittacosis/lymphogranuloma venereum virus (LGV) agents are similar. However, the replication of IBV and LGV in singly-infected cells under similar conditions differ significantly. After infection of HeLa cells with either virus, an RNA initial body is derived from each infectious unit. The initial body of IBV is usually found adjoining the cell nucleus (Furness et al. 1962), while that of LGV is characteristically away from the nucleus. In cells infected with more than one infectious particle LGV commonly induces several foci of infection, whereas cells infected with IBV have only a single infected centre adjoining the cell nucleus. The initial bodies of LGV stay in a circumscribed area, remain discrete and so can be shown to multiply exponentially for at least part of their cycle. As studied by our routine technique the initial bodies of IBV increase in size without evidence of multiplication, both in singly-infected cells and also in cells infected with several infectious units, where they appear to coalesce forming a large mass of RNA (Furness et al. 1962). We have since found that some of these masses of RNA disintegrate into particles similar to the initial bodies of LGV after mounting the infected monolayers, unfixed, in acridine orange stain and compressing the preparation before sealing with beeswax colophonium. This suggests that they are in fact clusters of initial bodies similar to those seen in cells infected with psittacosis virus (Bland \& Canti, 1935; Pollard, Starr, Moore \& Tanami, 1960). 
Journal of General Microbiology, Vol. 31, No. 1

Plate 1
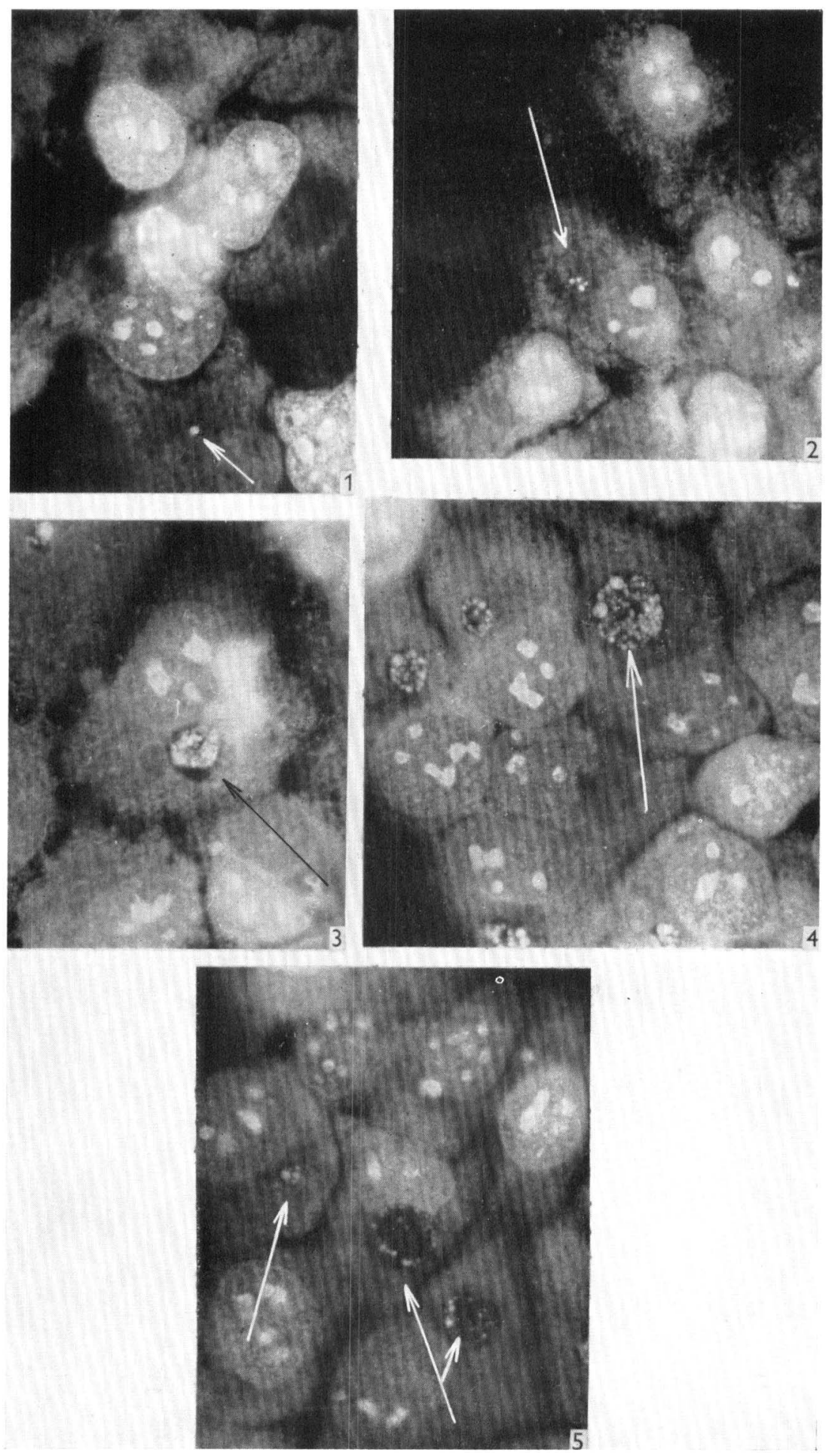

G. FURNESS AND G. W. CSONKA

(Facing p. 164) 

Differences in the rate of formation of the inclusions are not distinctive. The appearance of the infectious units or elementary bodies is, however, characteristic. After 18-21 hr. those of IBV are detectable as green-fluorescent DNA particles superimposed on the RNA mass. As the particles increase in number, filling the inclusion, the large masses of RNA gradually disintegrate, finally leaving an occasional RNA particle amongst the DNA particles. By contrast, in LGV at approximately the same time smaller orange to yellow particles are found amongst the initial bodies, which do not form clusters. These particles, which gradually replace the initial bodies, vary in diameter from 1 to $0 \cdot 25 \mu$, which is the diameter of the DNA particle of IBV, and in colour from orange to yellowish green. The infectious units or elementary bodies stain yellowish green and are without the green fluorescence typical both of DNA and of infective IBV. By treatment with nucleases both viruses can be shown to consist of DNA with an outer layer containing RNA. Thus the differences in staining properties are presumably attributable to a greater quantitity of RNA in the peripheral layer of the elementary bodies of LGV. These results confirm the original observations of Findlay, Mackenzie \& MacCallum (1938) and increase our knowledge of the replication of these microorganisms, but also reveal the complexity of their growth cycles, many stages of which remain obscure.

We wish to thank Professor C. F. Barwell for the JH strain of lymphogranuloma venereum virus and Miss Margaret Ham for her excellent technical assistance. The work of one of us (G. W. Csonka) was supported by a U.S. Public Health Service Grant administered by the Medical Research Council Working Party on Nonspecific Urethritis.

\section{REFERENCES}

Bland, J. O. W. \& CaNTi, R. G. (1935). The growth and development of psittacosis virus in tissue culture. J. Path. Bact. 40, 231.

Dulbecco, R. \& Vogt, M. (1954). Plaque formation and isolation of pure lines with poliomyelitis virus. J. exp. Med. 99, 167.

Findlay, G. M., Mackenzie, R. D. \& MacCallum, F. O. (1938). A morphological study of the virus of Lymphogranuloma inguinale (climatic bubo). Trans. Soc. trop. Med. Hyg. 32, 183.

Furness, G. \& Fraser, E. G. (1962). One-step growth curves for inclusion blennorrhoea virus in HeLa cell monolayers. J. gen. Microbiol. 27, 299.

Furness, G., Graham, D. M. \& Reeve, P. (1960). The titration of trachoma and inclusion blennorrhoea viruses in cell cultures. J. gen. Microbiol. 23, 618.

Furness, G., Henderson, D. W., Csonka, G. W. \& Fraser, E. F. (1962). A study by fluorescence microscopy of the replication of inclusion blennorrhoea virus in HeLa cell monolayers. J. gen. Microbiol. 28, 571.

Pollard, M., Stark, T. J., Moore, R. W. \& Tanami, Y. (1960). Cytochemical changes in human amnion cells infected with psittacosis virus. Nature, Lond. 188, $\mathbf{7 7 0 .}$

\section{EXPLANATION OF PLATE}

Plate 1. Growth cycle of lymphogranuloma venereum virus.

Fig. 1. $8 \mathrm{hr}$. One initial body.

Fig. 2. $12 \mathrm{hr}$. Four initial bodies.

Fig. 3. $20 \mathrm{hr}$. Uncountable number of initial bodies.

Fig. 4. $30 \mathrm{hr}$. Inclusion body containing both initial and elementary bodies.

Fig. 5. $44 \mathrm{hr}$. Inclusion bodies with fewer particles and cluster of initial bodies in previously uninfected cell. 